INTERNATIONAL MONETARY FUND
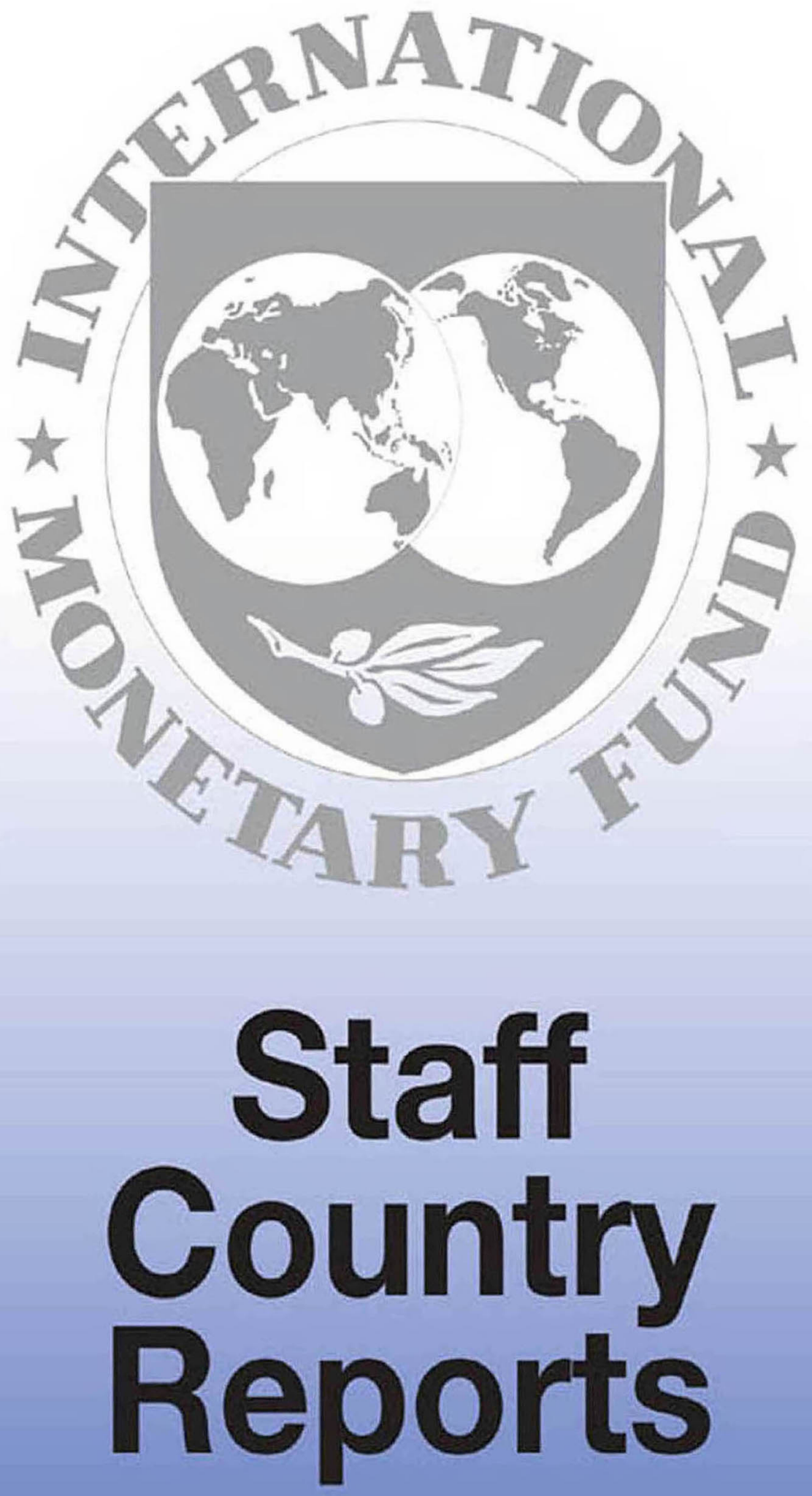


\section{Georgia: Report on Observance of Standards and Codes-FATF Recommendations for Anti-Money Laundering and Combating the Financing of Terrorism}

This Report on the Observance of Standards and Codes on the FATF Recommendations for Anti-Money Laundering and Combating the Financing of Terrorism for Georgia was prepared by a team of the International Monetary Fund using the assessment methodology adopted by the FATF in February 2004 and endorsed by the Executive Board of the IMF in March 2004. The views expressed in this document, as well as in the full assessment report, are those of the IMF team and do not necessarily reflect the views of the Government of Georgia or the Executive Board of the IMF.

Copies of this report are available to the public from

International Monetary Fund $\bullet$ Publication Services

700 19th Street, N.W. • Washington, D.C. 20431

Telephone: (202) 6237430 • Telefax: (202) 6237201

E-mail: publications@imf.org • Internet: http://www.imf.org

\section{International Monetary Fund Washington, D.C.}




\section{INTERNATIONAL MONETARY FUND}

\section{GEORGIA}

Report on Observance of Standards and Codes (ROSC)—FATF Recommendations for Anti-Money Laundering and Combating the Financing of Terrorism (AML/CFT)

Prepared by the Legal Department

Approved by Sean Hagan

December 2012 


\section{A. Introduction}

This Report on the Observance of Standards and Codes for the FATF 40 Recommendations for Anti-Money Laundering (AML) and 9 Special Recommendations on Combating the Financing of Terrorism (CFT) was prepared by the IMF. ${ }^{1}$ The report provides a summary of the AML/CFT measures in place in Georgia and of the level of compliance with the FATF 40+9 Recommendations, and contains recommendations on how the AML/CFT system could be strengthened. The assessment is based on the information available at the time of the mission from November 28 to December 13, 2011 and was conducted using the 2004 Assessment Methodology. The Detailed Assessment Report (DAR) on which this document is based was adopted by the Committee of Experts on the Evaluation of Anti-Money Laundering Measures and the Financing of Terrorism (MONEYVAL) plenary on July 3, 2012. The views expressed here, as well as in the full assessment report, are those of the staff team and do not necessarily reflect the views of the Government of Georgia or the Executive Board of the IMF.

\section{B. Key Findings}

\section{The Georgian AML/CFT regime has significantly improved since the last}

assessment in 2007. The amendments to the legal framework enacted between 2008 and February $2012^{2}$ have improved technical compliance with the FATF recommendations, in particular with respect to the criminalization of ML and FT and the preventive measures for financial institutions. Significant progress has been made since 2007 with regard to the effective use of the ML criminal provisions, provisional and confiscation measures, and international cooperation.

\section{However, weaknesses remain with regard to compliance with key elements of the} standard. A combination of technical deficiencies, poor implementation, and limited resources undermine the effectiveness of the financial intelligence unit (FIU) and AML/CFT supervision. In addition, there are still major loopholes in terms of transparency of legal entities, domestic cooperation, measures to prevent terrorism financing, and preventive measures for designated non-financial businesses and professions (DNFBPs).

3. These weaknesses should be urgently addressed in light of the significant ML/FT vulnerabilities and threats. These include: i) customers that are, or are owned by, offshore companies for which the identity of their beneficial owners is unknown or where the identity

\footnotetext{
${ }^{1}$ The assessment team consisted of Emmanuel Mathias (team leader); Kristel Poh, Chady El-Khoury, Marilyne Landry, Rocío Ortiz-Escario (all LEG), and Gabriele Dunker (LEG consultant).

${ }^{2}$ A number of changes to the legal framework were enacted between December 2011 and early February 2012, during the eight-week period following the mission. While their technical compliance with the standard was assessed, the assessment of their implementation has not been possible.
} 
has not been verified; ii) a rapid and ongoing increase of nonresident deposits; iii) the development of private banking activities, including a clientele of foreign politically-exposed persons (PEPs); iv) the rapid growth of the casino business and rising number of non-faceto-face transactions; v) the existence of large Georgian-led criminal organizations abroad which exposes the risk of proceeds of crime being transferred back to Georgia; and vi) domestic statistics demonstrating the existence of major proceeds-generating crimes, such as corruption, tax evasion, and drug trafficking.

\section{Legal Systems and Related Institutional Measures}

\section{Georgia has a comprehensive legal framework in place criminalizing both ML} and FT as autonomous offenses. ML is criminalized through three separate provisions in the Criminal Code. The provisions are in line with the Vienna and Palermo Conventions. In particular, all categories of predicate offenses listed in the international standard are covered, the ML offenses extend to any type of property that represents the proceeds of crime, and all acts constituting an ancillary offense to ML are criminalized.

\section{While no shortcomings have been identified in the legal framework, concerns} remain with respect to the implementation of the ML provisions. Based on statistics provided by the authorities, the ML provisions do not seem to be applied effectively to combat the most prevalent proceeds generating crimes, or to combat transnational organized crime. The modest number of legal persons investigated or prosecuted for ML raises concern since the authorities indicated the widespread use of companies in ML schemes. The statutory sanctions available are proportionate. However, the very liberal and frequent use of plea agreements, including in the majority of aggravated ML cases, undermines the dissuasive effect thereof.

\section{FT is criminalized under Georgian law broadly in line with the FATF standard.} However, some legal shortcomings remain. In particular, the requirement for an act to "infringe upon public safety etc." to qualify as a terrorist act unduly narrows the scope of the terrorism offense. The scope of the definition of the term "terrorist acts" does not fully cover the offenses defined in the Convention for the Suppression of Unlawful Acts against the Safety of Civil Aviation and the International Convention for the Suppression of Terrorist Bombings. The definitions of the terms "terrorist" and "terrorist organization" should be expanded to extend to all "terrorist acts" as defined under the FATF standard. At the time of the on-site mission, prosecutions of three persons for terrorism financing were ongoing. There had been no convictions for terrorism financing.

\section{Provisional and conviction-based confiscation measures are available with} respect to all predicate offenses, as well as the ML and FT offenses, and are applicable to proceeds as well as instrumentalities of crime. Confiscation is a mandatory sanction and may be applied against property equivalent in value to the proceeds of crime. Around US\$13 million has been confiscated since 2005 in the context of ML offenses. However, statistics provided by the authorities suggest that the legal provisions could be applied more 
effectively to confiscate proceeds of other types of crimes. Concerns also remain in relation to the authorities' practice to apply confiscation measures only in cases where property is actually available for confiscation at the time of conviction.

8. Georgia has established a framework to implement the relevant United Nations Security Council Resolutions (UNSCRs) and amended this framework in December 2011. The revisions constitute a significant improvement of Georgia's framework to implement its obligations under international law. However, given its very recent enactment, the effectiveness of the new framework could not be established.

\section{The FIU should further strengthen performance of its core functions. Some} sectors are not under a legal obligation to report suspicious transactions (real estate agents, lawyers, trust and company service providers (TCSPs), and electronic money institutions), thus the FIU is not capable of requesting additional information from them. The quality of analysis of suspicious transaction reports (STRs) is poor, mostly due to lack of analytical tools and weak quality of reporting, and limited use of its powers to access law enforcement information on ongoing investigations and prosecutions, or information from financial and nonfinancial institutions other than banks. In recent years, the FIU's increased workload was handled without a corresponding increase in its budget and a significant decrease in human resources.

10. Although the framework for law enforcement authorities is broadly in place, there is room for improvement in implementation. Since the decision of the Minister of Justice in 2010 recommending initiating ML investigations when law enforcement agencies (LEAs) suspect the presence of illegal proceeds, the number of ML investigations has increased. LEAs started to make better use of their powers and available investigative techniques. However, LEAs still lack the power to access information held by lawyers when the latter conduct financial activities on behalf of their clients. LEAs also need to increase their reliance on financial analysis and investigation techniques, in particular in relation to stand-alone money laundering cases, to trace the origin of the illegal funds, detect patterns between suspects and associates, and to identify the ultimate beneficial owners of legal persons, accounts, and transactions, and share this information between different agencies and departments.

\section{The measures in place to detect the physical cross-border transportation of} currency and bearer negotiable instruments are not comprehensive, nor effective. Customs or other competent authorities do not have the power to stop and investigate the movement of cash and bearer negotiable instruments unless they deem the relevant conduct to be smuggling. Only a small percentage of inbound and outbound movements of currency and bearer negotiable instruments are actually declared. 


\section{Preventive Measures - Financial Institutions}

12. The scope of Georgian preventive measures for the financial sector has been recently updated and is relatively comprehensive. However, it does not cover factoring and credit card services (currently offered only by banks), as well as electronic money and investment funds. Some forms of money value transfer (MVT) operators are not subject to regulation and supervision. They include electronic money institutions, casino accounts operated to move value within Georgia, and self-service terminals accepting cash and providing transfer facilities (known as Pay-boxes).

13. While most of the customer due diligence (CDD) and record-keeping provisions required under the international standard are in place, their implementation and effectiveness are limited. There are still some deficiencies in the legal framework, such as the lack of a prohibition on numbered accounts, the existence of a minimum monetary threshold for when standard CDD must be carried out, inconsistencies relating to measures that can be applied on a risk-sensitive basis, and the timing for undertaking CDD. In addition, implementation is generally poor regarding the identification and verification of beneficial owners, documentation of the purpose and nature of the account business, ongoing customer due diligence, and the application of risk-sensitive measures to customers. There are still major legal shortcomings regarding reliance on third parties and introduced business, as well as the monitoring of wire transfers.

\section{The requirement for reporting ML and FT suspicious transactions and other} information is largely in line with the standard; however, its implementation should be improved. The number of STRs submitted to the FIU is relatively high. Most of them are filed by banks. Electronic money institutions are not required to report and other sectors are not filing suspicious reports (i.e., leasing, insurance companies). The number of STRs can be explained by financial institutions' reliance on a system based on fixed indicators triggering automatic reports, and by a tendency of defensive reporting. Overall, the quality of STRs is poor and reporting entities are confused about the distinction between requirements to monitor transactions and those to report suspicious transactions, particularly as there is no appropriate guidance. While there are known FT risks in Georgia, no FT-related STRs have ever been received by the FIU.

15. Internal control and compliance provisions need to be strengthened, particularly for money remittance operators and currency exchange bureaus. These professions are not required to ensure that the AML compliance officer and other relevant staff have timely access to customer information, nor are they obliged to screen their employees and provide adequate AML/CFT training. There is also no requirement for nonbank financial institutions to have an adequately resourced and independent audit function. Internal control requirements pertaining to CFT were added for all financial institutions after the mission and were, therefore, not assessed. 
16. The National Bank of Georgia (NBG) has introduced many notable improvements to its supervisory framework since the onsite visit, but has limited resources for AML/CFT supervision. The NBG exercises regulatory and supervisory oversight over the financial institutions (around 1,700 institutions), it has only 5 staff for onsite AML/CFT inspection. Electronic money institutions are not yet subject to AML/CFT supervision. Given its limited resources, the supervisory cycle has been quite long for some institutions, such as currency exchange bureaus and money remittance operators.

Furthermore, there has been a lack of systematic off-site monitoring and on-site supervisory planning. Pecuniary sanctions available under sectorial regulations are low for several categories of violations (such as CDD requirements) to be considered as dissuasive and effective. Improvements have been introduced but are too recent to be assessed.

\section{Significant reforms have been recently introduced to the market entry}

framework. As these took place after the on-site mission, their implementation has not been reviewed. At the time of the onsite visit, there were no fit or proper tests for owners and administrators for a number of categories of financial institutions.

\section{E. Preventive Measures - Designated Non-Financial Businesses and Professions} (DNFBPs)

\section{The preventive measures for DNFBPs are substantially similar to those} applicable to financial institutions; however, their implementation is at its early stages. Preventive measures only apply to notaries, casinos, dealers in precious metals and stones and, more recently, accountants. Notaries have implemented the majority of CDD requirements but the identification of beneficial owners presents some challenges. Reporting levels for notaries are relatively low for the number of transactions being conducted and implementation of internal control requirements is weak. The same observation can be made in respect of casinos, where there is little to no compliance with requirements other than customer identification. No STRs have been reported by casinos despite the rapid growth of this industry. Obligations for dealers in precious metals and stones have not been implemented and accountants have only been subject to the AML/CFT requirements since January 2012. The absence of requirements for lawyers, real estate, and Trust and Company Service Providers (TCSPs) exacerbates the risk in these already vulnerable sectors.

19. With the exception of notaries, DNFBPs are not supervised. A number of supervisory authorities have been designated as AML/CFT supervisors in their respective areas of responsibility. However, other than activities undertaken by the Ministry of Justice pertaining to notaries, no AML/CFT examinations have been conducted.

\section{F. Legal Persons and Arrangements \& Non-Profit Organizations}

\section{In light of the risk that criminals integrate proceeds generated abroad in} Georgia or use Georgian entities to invest abroad, the inability to ensure adequate and accurate information on beneficial ownership of legal entities is a serious weakness. The recent establishment of the National Agency of Public Registry (NAPR) has enhanced access 
to information on legal persons. However, at the time of the mission, most of the data included in existing registries had not been migrated nor updated. Bearer shares exist under Georgian law but except for listed companies, there are no appropriate measures to ensure that bearer shares are not misused for money laundering.

21. The measures in place in Georgia relating to nonprofit organizations (NPOs) are deficient and do not adequately address the risks in Georgia. No formal review of the sector has been carried out, and there is no formal supervision of the sector. The NAPR provides publicly-available information on NPOs registered since 2010; however, data prior to 2010 is deemed to be unreliable. There is a lack of outreach to the NPO sector. Domestic coordination mechanisms related to NPOs are weak and there is no appropriate point of contact and procedures to respond to international requests related to NPOs.

\section{G. National and International Co-operation}

\section{Georgia does not have a central coordinating body/committee to steer and} coordinate the development and implementation of policies and activities to combat ML and TF. There is no mechanism allowing for cooperation between the supervisory agencies of FIs and DNFBPs, notably the NBG, the Ministry of Justice, and the Ministry of Finance.

23. Georgia's mutual legal assistance (MLA) framework is solid and allows for the provision of a wide range of assistance to foreign countries in the context of criminal investigations and prosecutions. Such assistance does not seem to be subject to any unduly restrictive or unreasonable requirements. While some of the grounds for refusal of MLA are drafted in a rather general manner, the low number of rejected requests leads to the conclusion that in practice these provisions are interpreted in a narrow manner. Both ML and FT are extraditable offenses. For those types of assistance that require dual criminality to be met, the shortcomings noted with respect to the FT offense may limit Georgia's ability to provide MLA or extradite a person in certain cases. Georgia's lack of diplomatic relations with Russia constitutes a practical challenge to effectively provide and receive international cooperation in ML and FT cases.

\section{International cooperation mechanisms are in place for the FIU, LEAs, and} supervisors. Information exchanged with foreign FIUs is comprehensive; however, timeliness could be improved and the FIU would benefit from making more proactive use of international collaboration channels. The NBG is responsive to requests from foreign supervisors but could make additional use of cooperation mechanisms to help ascertain if fitand-proper criteria are met. LEAs exchange information through a variety of channels including Interpol as well as bilateral and multilateral agreements. However, there is a lack of a clear legal basis that allows LEAs to compel production of information detained by lawyers based on international requests. 


\section{Summary Table of Observance and Key Recommendations}

Compliant (C): the Recommendation is fully observed with respect to all essential criteria.

Largely compliant (LC): there are only minor shortcomings, with a large majority of the essential criteria being fully met.

Partially compliant (PC): the country has taken some substantive action and complies with some of the essential criteria.

Non-compliant (NC): there are major shortcomings, with a large majority of the essential criteria not being met.

Not applicable (NA): a requirement or part of a requirement does not apply, due to the structural, legal or institutional features of a country.

\begin{tabular}{|c|c|}
\hline $\begin{array}{c}\text { FATF 40+9 } \\
\text { Recommendations } \\
\text { and Ratings }\end{array}$ & Key Assessor Recommendations \\
\hline \multicolumn{2}{|c|}{ Legal System and Related Institutional Measures } \\
\hline
\end{tabular}

\begin{tabular}{|l|l}
$\begin{array}{l}\text { Criminalization of } \\
\text { Money Laundering }\end{array}$ & $\begin{array}{l}\text { Utilize the option to enter into a plea agreement in a more selective manner, in } \\
\text { particular in the context of aggravated offenses, and ensure that in all other cases, the } \\
\text { sanctions regime for ML is applied in a dissuasive and effective manner. }\end{array}$ \\
\hline
\end{tabular}

R.1 LC

R.2 LC

- Review the approach taken in applying the ML provisions to ensure that the strong legal framework in place is used to combat predicate crime effectively both in a domestic and transnational context. In particular, a proactive approach should be put on investigating and prosecuting those persons that orchestrate and control ML schemes through Georgia. Law enforcement authorities should also address financial flows in their investigations for predicate offenses to detect any potential ML activities.

Criminalization of

Terrorist Financing

SR.II PC
- Amend Article 323 to remove the requirement that an act "infringes upon public safety, etc."

- Criminalize all offenses defined in the Convention for the Suppression of Unlawful Acts Against the Safety of Civil Aviation and include them within the scope of Article 331/1.

- Ensure that offenses under the International Convention for the Suppression of Terrorist Bombings fall within the scope of Article 331/1 also in cases where no terroristic intent can be proven.

- Define the terms "terrorist" and "terrorist organization" in line with the FATF standard by covering within the scope of "terrorist activity" all terrorist acts as defined under the FATF standard.

Confiscation, freezing, and seizing of proceeds of crime

- Review the scope of legal privilege and make more frequent use of the confiscation framework by applying the confiscation provisions in all cases.

\section{R.3 LC}

Freezing of funds used for terrorist financing

SR.III PC

- Amend Article 21/31 of the Administrative Procedures Code in order to clarify that an application for a freezing order must be considered "grounded" by the courts whenever a person is designated by the UN Sanctions Committed under UNSCR 1267.

- Ensure that freezing measures under UNSCR 1267 and 1373 are applied "without delay" including where such measures are requested by a foreign authority, and consider whether the 15-day period granted under Article 21/32 of the Administrative Procedures Code to issue a freezing order is too permissive. "Without delay" should be interpreted to mean within a matter of hours from the designation of the person.

- Remove the court's power to review a freezing order in relation to UN-designated persons, groups, or entities.

- Ensure that there are adequate processes in place to grant access to frozen funds for necessary or extraordinary expenses in line with the requirements under UNSCR 1452.

- Issue more detailed guidance to monitoring entities on how to implement their obligations under freezing orders.

- Ensure that monitoring entity's compliance with the obligations under freezing orders is appropriately monitored.

The Financial Intelligence Unit and
- Amend the AML/CFT Law to require the real estate agents, lawyers, TCSPs, and electronic money institutions to report suspicious transactions that will enhance the 


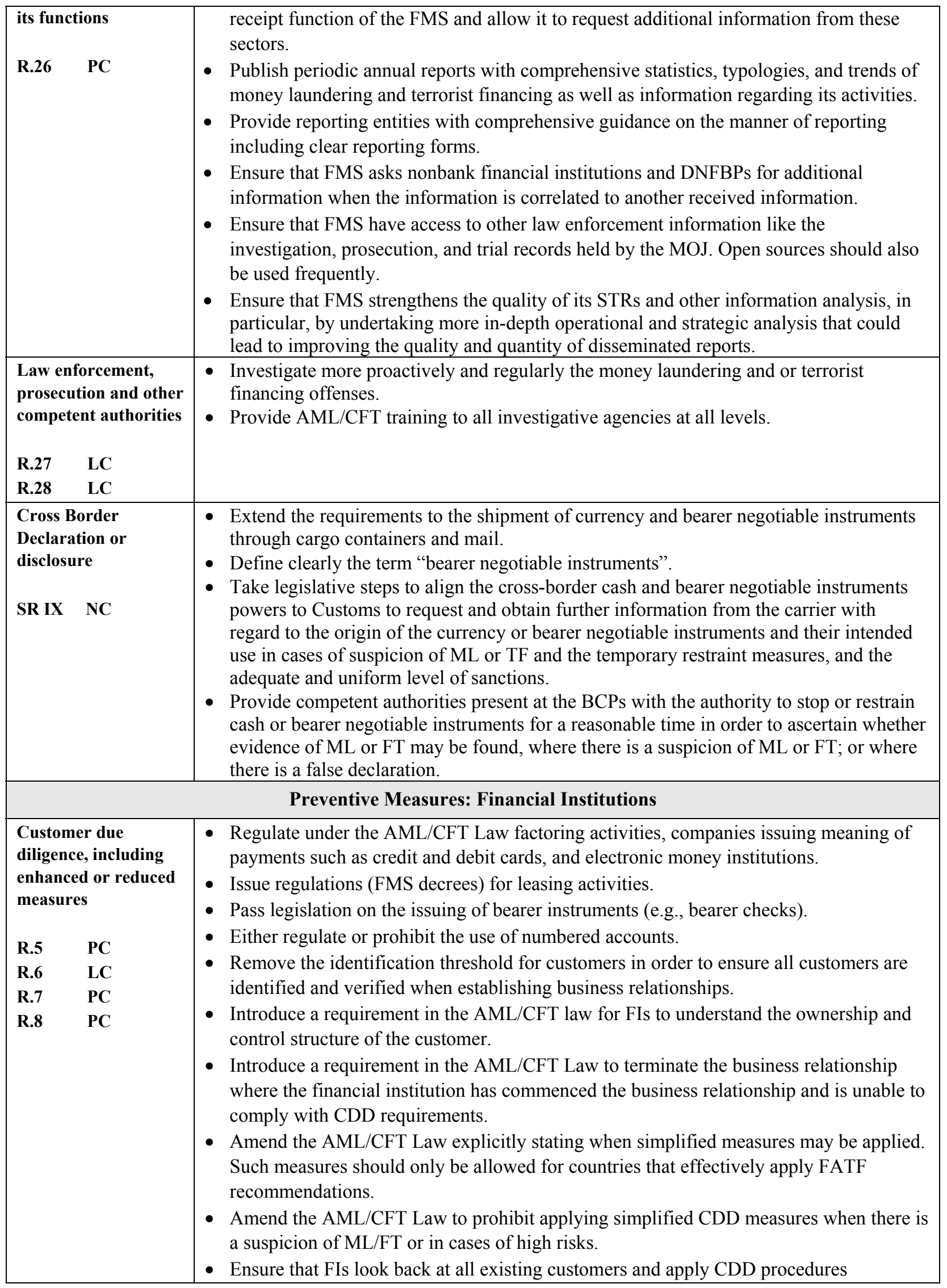




\begin{tabular}{|c|c|}
\hline & $\begin{array}{l}\text { - Eccording to the new AML/CFT Law on a risk basis. } \\
\text { of the beneficial owner and on the information of purpose and nature of business. } \\
\text { - Ensure that full CDD measures are applied to all existing customers. } \\
\text { - Regulate the cases where FIs may complete the verification of the identity of the } \\
\text { customers and beneficial owner after the establishment of the relationship. } \\
\text { - Ensure that EDD apply when PEPs are beneficial owners of legal arrangements } \\
\text { - Ensure that financial institutions take reasonable measures to ascertain the source of } \\
\text { wealth of the customer and their compliance with the new AML requirements for PEPs. } \\
\text { - Ensure that FIs apply enhanced ongoing monitoring in business relationships with } \\
\text { PEPs. } \\
\text { - Require that financial institutions that engage in correspondent banking activities } \\
\text { - } \text { Eocument the respective responsibilities of each institution. } \\
\text { - Ensure that correspondent relationships are approved by senior management. } \\
\text { relationships with respect to AML/CFT issues and assess the possible reputational risks } \\
\text { arising from those relationships. } \\
\text { - Clarify that, when determining the reputation of a respondent institution, financial } \\
\text { institutions should also determine from publicly available information if the respondent } \\
\text { institution has been subject to a money laundering or terrorist financing investigation or } \\
\text { regulatory action. } \\
\text { - Ensure that entities have in place identification and verification procedures and develop } \\
\text { enhanced measures to control and mitigate non-face-to-face business relationships and } \\
\text { the use of new technology risks for all FIs. } \\
\text { - Ensure that entities apply adequate ongoing CDD to non-face-to-face customers. } \\
\text { - Clarify and issue guidelines on the use of non-face-to-face channels. } \\
\text { - Ensure that AML/CFT provisions cover the operations regulated in the Instruction on } \\
\text { Opening of an Account and Foreign Currency Operation which allows under certain } \\
\text { circumstances to open a current account without physical presence and send the } \\
\text { documentation by postal mail. }\end{array}$ \\
\hline $\begin{array}{l}\text { Third parties and } \\
\text { introduced business }\end{array}$ & $\begin{array}{l}\text { - Require that financial institutions are satisfied that the third party has measures in place } \\
\text { to comply with the CDD requirements set out in R.5 and R.10. } \\
\text { - Amend the AML/CFT law to require financial institutions relying on third parties } \\
\text { immediately to obtain from the third party the necessary information related to all CDD } \\
\text { process. } \\
\text { - Ensure that competent authorities take into account information available on whether } \\
\text { the countries in which the third party can be based adequately apply the FATF } \\
\text { Recommendations. }\end{array}$ \\
\hline $\begin{array}{l}\text { Financial institution } \\
\text { secrecy or } \\
\text { confidentiality }\end{array}$ & $\begin{array}{l}\text { - Ensure that the AML Law and the sectoral laws for all licensed financial institutions } \\
\text { contain consistent provisions (and exceptions) relating to confidentiality to ensure the } \\
\text { FMS' access to financial institutions' records. } \\
\text { - Amend the sectoral laws to allow financial institutions to exchange and share } \\
\text { information for the purpose of Recommendation } 9 \text { and Special Recommendation VII for } \\
\text { AML purposes, even in the absence of customer consent. }\end{array}$ \\
\hline $\begin{array}{l}\text { Record keeping and } \\
\text { wire transfer rules }\end{array}$ & $\begin{array}{l}\text { - Empower other competent authorities than the NBG to request an extension of the } \\
\text { record keeping obligations. } \\
\text { - Ensure FIs implement AML requirements in an adequate way, especially regarding the } \\
\text { time reference applied to record keeping requirements the AML Law. } \\
\text { - Ensure that all domestic and cross-border transfers are adequately monitored and }\end{array}$ \\
\hline
\end{tabular}




\begin{tabular}{|c|c|}
\hline & $\begin{array}{l}\text { supervised in terms of ML/FT risk management. } \\
\text { - Amend the AML/CFT Law and FMS Decrees to ensure that there is an obligation for } \\
\text { the intermediary to transmit the originator information along the messages chain in all } \\
\text { cases. } \\
\text { - Require beneficiary institutions to adopt effective risk-based procedures for identifying } \\
\text { and handling wire transfers that are not accompanied by complete originator } \\
\text { information. } \\
\text { - Ensure that nonbanking institutions carrying out wire transfer are compliance with the } \\
\text { AML law. }\end{array}$ \\
\hline $\begin{array}{l}\text { Monitoring of } \\
\text { transactions and } \\
\text { relationships }\end{array}$ & $\begin{array}{l}\text { - Ensure that the legal basis for unusual and watch zone related transaction is clear and } \\
\text { comprehensive } \\
\text { - Provide FIs with guidelines on the implementation of the requirement to pay special } \\
\text { attention to unusual and watch zone related transactions and amend the reporting forms } \\
\text { to exclude the unusual and watch zone related transactions from the breakdown list. } \\
\text { - Update the watch zone list to include countries identified by FATF which do not or } \\
\text { insufficiently apply FATF Recommendations. } \\
\text { - Provide for the possibility to apply counter-measures in cases where a country continues } \\
\text { to not apply or apply insufficiently the FATF Recommendations. }\end{array}$ \\
\hline $\begin{array}{ll}\text { R.13 } & \text { LC } \\
\text { R.14 } & \text { LC } \\
\text { R.19 } & \text { C } \\
\text { R.25 } & \text { PC } \\
\text { SR.IV } & \text { LC }\end{array}$ & $\begin{array}{l}\text { - Require electronic money institutions companies to report STRs. } \\
\text { - Amend the FT offence to bring it in line with the FT convention. } \\
\text { - Amend Article } 12 \text { of the AML Law to ensure that protection and tipping-off } \\
\text { requirements are in line with the standard. } \\
\text { - Provide guidance to FIs to clarify the different types of reporting, i.e. suspicious and } \\
\text { threshold. } \\
\text { - Assist the FIs in understanding the requirement on monitoring or paying special } \\
\text { attention to unusual transactions and those related to watch zone. } \\
\text { - Establish a mechanism for providing feedback to reporting institutions, including } \\
\text { general and specific or case-by-case feedback. } \\
\text { - Strengthen the guidelines and feedback across all sectors to: (i) incorporate different } \\
\text { examples covering sectors other than banking; and (ii) provide more Georgian examples } \\
\text { of money laundering and terrorist financing typologies. }\end{array}$ \\
\hline $\begin{array}{l}\text { Internal controls, } \\
\text { compliance, audit } \\
\text { and foreign branches }\end{array}$ & $\begin{array}{l}\text { - For money remittance operators and currency exchange bureaus, introduce a provision } \\
\text { to ensure that the AML officer and other appropriate staff have timely access to } \\
\text { customer identification data and other relevant information. } \\
\text { - Introduce a provision for money remittance operators and currency exchange bureaus } \\
\text { on employee screening procedures. } \\
\text { - Establish a requirement for financial institutions to have an adequately resourced and } \\
\text { independent audit function for AML purposes. } \\
\text { - For money remittance operators and currency exchange bureaus, expand the provision } \\
\text { on AML training to indicate that the training should be provided on an ongoing basis to } \\
\text { ensure that employees are kept informed of new developments, and that there is a clear } \\
\text { explanation of all aspects of AML/CFT laws and obligations, and in particular, } \\
\text { requirements concerning CDD and suspicious transaction reporting. }\end{array}$ \\
\hline R.18 LC & $\begin{array}{l}\text { - Introduce a specific provision that explicitly requires FIs to satisfy themselves that their } \\
\text { respondent financial institutions do not permit their accounts to be used by shell banks. }\end{array}$ \\
\hline $\begin{array}{l}\text { Supervisory and } \\
\text { oversight system- } \\
\text { competent authorities } \\
\text { and SROs } \\
\text { Role, functions, } \\
\text { duties and powers } \\
\text { (including sanctions) }\end{array}$ & $\begin{array}{l}\text { - Review and increase the amount of monetary fines for several categories of violations } \\
\text { to ensure that the fines are punitive and dissuasive. } \\
\text { - Include proper sanctions against electronic money institutions for non-compliance with } \\
\text { AML/CFT requirements. } \\
\text { - Implement the introduction of fit and proper tests for several categories of financial } \\
\text { institutions; establish an AML off-site function; and develop a supervisory plan for on- } \\
\text { site inspections. }\end{array}$ \\
\hline
\end{tabular}




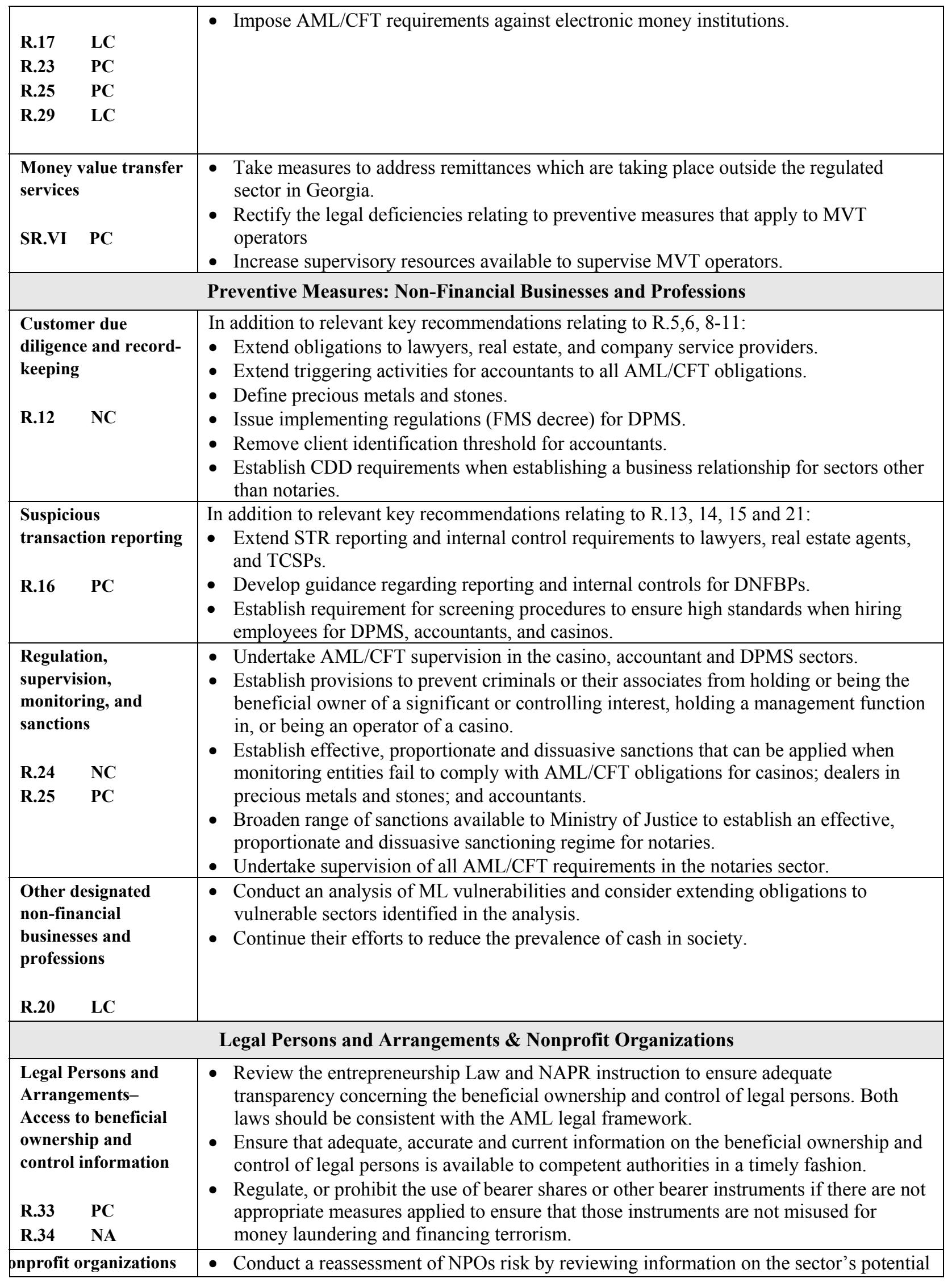




\begin{tabular}{|c|c|c|}
\hline \multicolumn{2}{|c|}{ SR.VIII PC } & $\begin{array}{l}\text { vulnerabilities. } \\
\text { - Establish effective supervision or monitoring of NPOs. } \\
\text { Establish appropriate measures to sanction violations of oversight measures or rules by } \\
\text { NPOs. }\end{array}$ \\
\hline \multicolumn{3}{|r|}{ National and International Cooperation } \\
\hline $\begin{array}{l}\text { Nation: } \\
\text { and cos }\end{array}$ & $\begin{array}{l}\text { I cooperation } \\
\text { rdination }\end{array}$ & $\begin{array}{l}\text { Put in place effective mechanisms between policy makers, the FMS, LEAs and } \\
\text { supervisors which enable them to cooperate and, where appropriate, coordinate } \\
\text { domestically with each other concerning the development and implementation of } \\
\text { policies and activities to combat ML and TF. } \\
\text { - Review statistics in the relevant areas of the fight against ML and TF on a regular basis } \\
\text { to assess the effectiveness of the AML/CFT regime. }\end{array}$ \\
\hline \multicolumn{2}{|c|}{$\begin{array}{l}\text { The Conventions and } \\
\text { UN Special } \\
\text { Resolutions }\end{array}$} & $\begin{array}{l}\text { - Implement fully the Vienna, Palermo, and FT Conventions. } \\
\text { - Address the shortcomings identified in relation to the implementation of UNSCRs } 1267 \\
\text { and } 1373 \text {. }\end{array}$ \\
\hline $\begin{array}{l}\text { R.36 } \\
\text { R.37 } \\
\text { R.38 } \\
\text { SR.V }\end{array}$ & $\begin{array}{l}\text { LC } \\
\text { C } \\
\text { LC } \\
\text { PC }\end{array}$ & $\begin{array}{l}\text { - Review the scope of legal privilege to ensure that LEAs' powers to trace proceeds and } \\
\text { instrumentalities of crime are not negatively affected, including where such measures } \\
\text { are requested by a foreign state. } \\
\text { - Define the FT offense fully in line with the FATF standard to ensure that Georgia's } \\
\text { ability to provide MLA is not limited in cases where dual criminality is required. } \\
\text { - Provide MLA to all countries, including all countries in the region. }\end{array}$ \\
\hline $\begin{array}{l}\text { R.39 } \\
\text { R.37 } \\
\text { SR.V }\end{array}$ & $\begin{array}{l}\text { LC } \\
\text { C } \\
\text { PC }\end{array}$ & $\begin{array}{l}\text { - Define the FT offense fully in line with the FATF standard to ensure that Georgia's } \\
\text { ability to extradite a person is not limited due to the requirement of dual criminality. } \\
\text { - Set out mechanisms and procedures to ensure timely handling of extradition requests. }\end{array}$ \\
\hline $\begin{array}{l}\text { Other I } \\
\text { Cooper }\end{array}$ & $\begin{array}{l}\text { orms of } \\
\text { ation }\end{array}$ & $\begin{array}{l}\text { - Authorities provide a clear legal basis that allows compelling production by LEAs of } \\
\text { financial transactions detained by lawyers based on international requests. } \\
\text { - FMS be more proactive in requesting information from foreign counterparts. } \\
\text { - NBG uses MOUs to determine compliance with fit and proper criteria. } \\
\text { - FMS and NBG share information spontaneously with counterparts. } \\
\text { - FMS negotiates agreements with FIUs and financial supervisors located in off-shore } \\
\text { jurisdictions, most commonly found in financial investigations. } \\
\text { - Maintain comprehensive statistics on international cooperation. }\end{array}$ \\
\hline \multicolumn{3}{|r|}{ Other Issues } \\
\hline $\begin{array}{l}\text { Resour } \\
\text { Statisti }\end{array}$ & $\begin{array}{l}\text { es \& } \\
\text { s }\end{array}$ & $\begin{array}{l}\text { - Provide competent authorities with adequate, relevant and specialized trainings on a } \\
\text { regular basis. Trainings on the risks and vulnerabilities of ML and FT, information } \\
\text { technology and other resources relevant to the execution of their functions, and assets } \\
\text { management are necessary. } \\
\text { - Increase the human and financial resources for the FMS and ensure full independence of } \\
\text { LEAs. } \\
\text { - Develop comprehensive and reliable statistics on property frozen or seized for each type } \\
\text { of predicate offense. } \\
\text { - Review the effectiveness of Georgia's AML/CFT systems on a regular basis. } \\
\text { - Maintain in a systematic fashion comprehensive statistics on international cooperation } \\
\text { by LEAs and supervisors, including whether the request was granted or refused. }\end{array}$ \\
\hline
\end{tabular}




\section{H. Authorities' Response}

Georgian authorities appreciate the time and efforts evaluators dedicated to the assessment of Georgian AML/CFT system. The authorities indicated that the recommendations of the Report have already been put into an Action Plan in order to implement appropriate corrective measures.

Georgian authorities would like to pay special attention to the instances where the opinions of the authorities and the assessors diverged. We note that out of 49 FATF Recommendations certain recommendations (e.g. R7, 11, 15, 25, 26) were rated as partially compliant without sufficient justification in the light of non-relevant interpretation of Georgian legislation.

First of all we would like to pay attention to Recommendation 7 where the large majority of essential criteria are fully met by the Georgian AML/CFT legal framework. The same situation is extended on Recommendation 11. Though, in this case evaluators' conclusions on effectiveness still remain rather subjective.

Furthermore, Georgian authorities consider that in case of Recommendation 15 the essential criteria are also fully met by the Georgian AML/CFT legislation. Only minor shortcomings are in place and they are related to currency exchange bureaus and money remittance services. It is worth to note that in most of cases these entities conduct their activities as sole entrepreneurs. Therefore, it will be a very high burden for them to introduce a requirement that they shall employee a separate person as an AML/CFT compliance officer.

As regards Recommendation 26, there are number of factual circumstances that have not been taken into consideration by the evaluators' team. Due to the requirements of the R26, such circumstances are the following:

- Publication of annual reports on the official web site of the FIU;

- Publication of guidance by the FMS for each monitoring entity on the manner of reporting (since the establishment of reporting obligations);

- For the purpose of conducting appropriately its functions the access of the FIU to the large number of databases for (list of databases are given in par 322).

Georgian authorities and the evaluators' team have also different positions on financial guarantees of the activity of the FIU. Since 2007 the budget of the FMS has only been increased that is quite obvious from paragraph 352. As regards increasing workload within the FMS, the issue has been resolved by the special software facilitating the process of data collection within FIU. This fact is also directly linked to the decreasing number of the staff of the FMS. Unfortunately, the evaluators' team did not take into account the mentioned circumstances that strictly underline the compliance of the current Georgian AML/CFT system to the relevant criteria. 
Georgian authorities would like to underline once more that based on the Action Plan of the Detailed Assessment Report we will continue our efforts in order to strengthen the AML/CFT legal framework of Georgia in compliance with FATF standards.

Finally, we would like to thank once again to the Assessment Team for their cooperation. 